\title{
Heel of the Hand
}

National Cancer Institute

\section{Source}

National Cancer Institute. Heel of the Hand. NCI Thesaurus. Code C161382.

The raised part of the palm of the hand that is adjacent to the wrist. 